\title{
MENGGAGAS KONSEP KESEJAHTERAAN DESA BERBASIS RISET PARTISIPASI
}

\author{
Ayudia Sokarina \\ Universitas Mataram \\ ayudia.sokarina@unram.ac.id
}

\begin{abstract}
ABSTRAK
Membebaskan identitas desa sebagai tempat bagi kaum marjinal menjadi tanggung jawab semua pihak. Peneleh Research Institute bekerja sama dengan Universitas Sulawesi Barat melakukan pengabdian kepada masyarakat di Desa Pamboborang, Kabupaten Banggae, Sulawesi Barat yang ditujukan untuk mengkontruksi strategi peningkatan kesejahteraan masyarakat berbasis riset partisipasi. Teknik pengumpulan data dalam kegiatan ini menggunakan diskusi kelompok terfokus, wawancara mendalam, dan mengobservasi. Hasilnya berupa pemetaan struktur sosial, ekonomi, dan budaya desa dalam mengidentifikasi isu pembangunan dan menggali potensi yang dimiliki desa, sehingga dapat digunakan sebagai bahan baku untuk merancang berbagai aksi pemberdayaan dalam mencapai kesejahteraan desa.
\end{abstract}

Kata Kunci: Desa, isu pembangunan, kaum marjinal, kesejahteraan, dan potensi.

\section{ABSTRACT}

Liberating the identity of the village as a place for the marginalized is the responsibility of all parties. The Peneleh Research Institute in collaboration with the University of West Sulawesi conducted community service in Pamboborang Village, Banggae Regency, West Sulawesi aimed at constructing a strategy to improve community welfare based on 
participatory research. Data collection techniques in this activity used focus group discussions, in-depth interviews, and observation. The result is a mapping of the social, economic, and cultural structure of the village in identifying development issues and exploring the potential of the village, so that it can be used as raw material for designing various empowerment actions in achieving village welfare.

Keywords: Village, development issues, marginalized people, welfare, and potential.

\section{PENDAHULUAN}

Masyarakat desa selama ini identik sebagai kaum termarjinalkan (Mulawarman et al. 2020). Adapun secara geografis, sebagian besar penduduk Indonesia tinggal di desa. Pembangunan dan perekonomian desa sering kali berbanding terbalik dengan wilayah kota, seperti: keterbatasan ketersediaan air bersih, kesulitan akses menuju desa, bahkan rendahnya tingkat pendapatan di desa yang dapat dipengaruhi oleh berbagai faktor, seperti minimnya lapangan pekerjaan, rendahnya pendidikan dan keterampilan masyarakat. Padahal banyak sekali potensi desa yang perlu digali dan dimanfaatkan guna meningkatkan kesejahteraan masyarakat.

Potensi desa bukan hanya ketersediaan sumber daya alam tetapi juga sumber daya manusia, sosial, lingkungan, dan budaya desa yang apabila dikelola dengan baik dapat memberikan manfaat bagi masyarakat. Guna mempercepat konstruksi peningkatan kesejahteraan desa, perlu peran berbagai pihak dalam mewujudkan sinergi yang positif. Baik pemerintah maupun peneliti dapat menjadi fasilitator untuk memberikan ide atau gagasan dalam merumuskan konsep kesejahteraan desa. Selain itu, partisipasi masyarakat sangat diharapkan dalam memberikan kontribusi baik sejarah maupun budaya berdasarkan kearifan lokal di daerahnya. Masyarakat berperan penting dalam kesuksesan mewujudkan kesejahteraan desa, karena dianggap lebih mengenal kebutuhan dan lingkungannya daripada pemerintah ataupun pihak ketiga. Dengan 


\section{Jurnal ABDIMAS INDEPENDEN}

Vol. 2, No. 2, November 2021

menggunakan metodologi Appreciative Inquiry, masyarakat turut terlibat dalam menentukan pemberdayaan desa. Riset tidak lagi hanya bersifat deduktif atau induktif, tetapi juga partisipatoris.

\section{METODE KEGIATAN}

Kegiatan pengabdian ini merupakan kerja sama antara Peneleh Research Institute dengan Universitas Sulawesi Barat yang dilaksanakan pada tanggal 2-4 April 2021 dan diikuti oleh 22 peneliti dari berbagai Universitas (lihat Tabel 1). Lokasi penelitian di Desa Pamboborang, Kecamatan Banggae, Sulawesi Barat. Teknik pengumpulan data dilakukan melalui diskusi kelompok terfokus, wawancara mendalam, dan mengobservasi beberapa informan (lihat Tabel 2).

Tabel 1. Daftar Peneliti

\begin{tabular}{|c|l|l|}
\hline No & \multicolumn{1}{|c|}{ Nama } & \multicolumn{1}{|c|}{ Instansi } \\
\hline 1 & Dr. Aji Dedi Mulawarman & Universitas Brawijaya \\
\hline 2 & Dr. Ari Kamayanti & Politeknik Negeri Malang \\
\hline 3 & Endriady Edy Abidin, S.IP., MA & $\begin{array}{l}\text { Pusat Studi Pedesaan, Universitas } \\
\text { Sulawesi Barat }\end{array}$ \\
\hline 4 & Ikawati Karim, S.TP., M.Si & $\begin{array}{l}\text { Pusat Studi Pedesaan, Universitas } \\
\text { Sulawesi Barat }\end{array}$ \\
\hline 5 & Andi Ismira, S.IP, MA & FISIP Universitas Sulawesi Barat \\
\hline 6 & Gia Ayu Fita, S.Sos., M.Si & FISIP Universitas Sulawesi Barat \\
\hline 7 & Muhammad Mukhram, S.Pd, M.Ak & FEKON Universitas Sulawesi Barat \\
\hline 8 & Dr. Abdul Hafid & $\begin{array}{l}\text { Pusat Studi Pedesaan, Universitas } \\
\text { Sulawesi Barat }\end{array}$ \\
\hline 9 & Dr. Muhammad Sultan & $\begin{array}{l}\text { Pusat Studi Pedesaan, Universitas } \\
\text { Sulawesi Barat }\end{array}$ \\
\hline 10 & Laila Qadriani, S.Si, M.Stat. & $\begin{array}{l}\text { Pusat Studi Pedesaan, Universitas } \\
\text { Sulawesi Barat }\end{array}$ \\
\hline 11 & Dr. Nur Indah Sari Arbit., S.Si, M.Si & $\begin{array}{l}\text { Pusat Studi Pedesaan, Universitas } \\
\text { Sulawesi Barat }\end{array}$ \\
\hline 12 & Purnamasari, S.Pd, M.Pd & $\begin{array}{l}\text { FEKON Universitas Cokroaminoto } \\
\text { Makasar }\end{array}$ \\
\hline 13 & Kasmiati, S.E, M.Si & FEKON Universitas Sulawesi Barat \\
\hline 14 & Suparjo Razasli. C., S.Si, M.Si & $\begin{array}{l}\text { Pusat Studi Pedesaan, Universitas } \\
\text { Sulawesi Barat }\end{array}$ \\
\hline 15 & Septri Legitasari Lere Jayanti & Universitas Sulawesi Barat \\
\hline 16 & Septiawan Ardiputra, SE., M.A.P & $\begin{array}{l}\text { Pusat Studi Pedesaan, Universitas } \\
\text { Sulawesi Barat }\end{array}$ \\
\hline
\end{tabular}




\begin{tabular}{|c|l|l|}
\hline 17 & Muhammad Yusri AR. S.IP., MA. & $\begin{array}{l}\text { Pusat Studi Pedesaan, Universitas } \\
\text { Sulawesi Barat }\end{array}$ \\
\hline 18 & Nursami, Amd., Keb & Puskesmas Banggae I \\
\hline 19 & Wulan Ayuandiani, SE., M.M & FEKON Universitas Sulawesi Barat \\
\hline 20 & Tikawati & Universitas Sulawesi Barat \\
\hline 21 & Dr. Novrida Qudsi Lutfillah & Universitas Wijaya Putra Surabaya \\
\hline 22 & Dr. Ayudia Sokarina & Universitas Mataram \\
\hline
\end{tabular}

Informannya dipilih secara acak berjumlah 8 orang (lihat Tabel 2). Sementara itu, kegiatan pengabdian ini melibatkan anggota peneliti dari bidan desa, sehingga pengidentifikasian isu pembangunan dan penggalian potensi desa terkait bidang kesehatan menjadi lebih mendalam diperoleh.

Tabel 2. Daftar Informan

\begin{tabular}{|l|l|l|c|l|}
\hline No & \multicolumn{1}{|c|}{ Nama } & Jenis Kelamin & Umur & \multicolumn{1}{c|}{ Keterangan } \\
\hline 1 & NS & Pria & - & \\
\hline 2 & J & Pria & - & \\
\hline 3 & U & Pria & - & \\
\hline 4 & R & Pria & - & \\
\hline 5 & IF & Wanita & 29 tahun & \\
\hline 6 & Nurasia & Wanita & 42 tahun & $\begin{array}{l}\text { Ibu pandai besi, Dusun } \\
\text { Galung Para }\end{array}$ \\
\hline 7 & Fatma & Wanita & 49 tahun & $\begin{array}{l}\text { Warga Dusun Galung } \\
\text { Para }\end{array}$ \\
\hline 8 & Jelati & Wanita & 43 tahun & $\begin{array}{l}\text { Warga Dusun Galung } \\
\text { Para Selatan }\end{array}$ \\
\hline
\end{tabular}

Pelaksanaan kegiatan pengabdian ini mengadopsi program Relawan Riset Peneleh yang merupakan program dari Peneleh Research Institute (PRI). Peneliti dituntut untuk berinteraksi secara langsung dengan masyarakat desa, dengan mendengarkan dan memperhatikan gagasangagasan masyarakat desa dan peneliti mengajukan pertanyaan yang dapat menggugah diskusi dan proses pembelajaran bersama tentang situasi desa (Arijanto 2017:128). Adapun kegiatan pengabdian ini menggunakan metodologi Appreciative Inquiry dengan tahapan, yaitu: tahap Menemukan (Discovery), tahap Memimpikan (Dream), tahap Merancang perubahan 
(Design) dan tahap Menformulasikan strategi pelaksanaan aksi perubahan (Deploy atau Destiny) yang disingkat 4D atau 4M (Arijanto 2021:80).

Pada tahap Menemukan (Discovery) atas isu pembangunan dan potensi desa, ada dua skenario yang bisa peneliti yang notabenenya adalah agen perubahan gunakan, yaitu melalui diskusi dengan pemangku kepentingan desa yang dimulai dengan menggali cerita sukses di desa. Apabila tidak berhasil, maka agen perubahan dapat menggunakan data sekunder dan kemudian ditriangulasi dengan data primer. Hasilnya dapat menjadi gerbang masuk untuk menggali potensi desa dan selanjutnya dapat diimplementasi dalam program-program aksi perubahan pemberdayaan desa. Selanjutnya pada tahap Memimpikan (Dream) pun dilakukan secara diskusi. Dengan menggunakan hasil temuan isu pembangunan dan penggalian potensi desa, maka dapat diimpikan kondisi ideal desa. Sementara tahap Merancang perubahan (Design) di mana membutuhkan kemampuan berpikir untuk menganalisis hubungan sebab akibat berdasarkan logframe. Terakhir, tahap Menformulasikan strategi pelaksanaan aksi perubahan di mana analisis peran dari organisasi masyarakat dan institusi pelayanan publik sangat dibutuhkan.

\section{HASIL DAN PEMBAHASAN}

\section{Pengidentifikasian isu Pembangunan dan Penggalian Potensi Desa}

Air bersih merupakan hal mendasar yang dibutuhkan manusia. Namun, beberapa rumah tangga di Desa Pamboborang mengalami ketidaktersediaan pasokan air di rumah masing-masing warga (bagi yang tidak memiliki mesin air). Sebenarnya desa memiliki toilet umum yang pembangunannya didanai dari PNPM Mandiri tahun 2014 tampak masih bagus secara fisik, tetapi tidak berfungsi dan tidak terurus karena tidak tersedia air (lihat Gambar 1). Setelah dikonfirmasi ke masyarakat bahwa ibuibu merasa tidak nyaman jika mandi di tempat umum. Oleh karena itu, perlu disediakan teknologi yang dapat mengalirkan air ke rumah-rumah warga dan 
disediakannya tandon publik, sehingga tidak perlu menggunakan mesin untuk mengalirkan air ke warga. Seperti halnya, di Desa Bantaeng yang mandiri sumber daya air dengan memanfaatkan gravitasi dan dikelola oleh BUMDES.

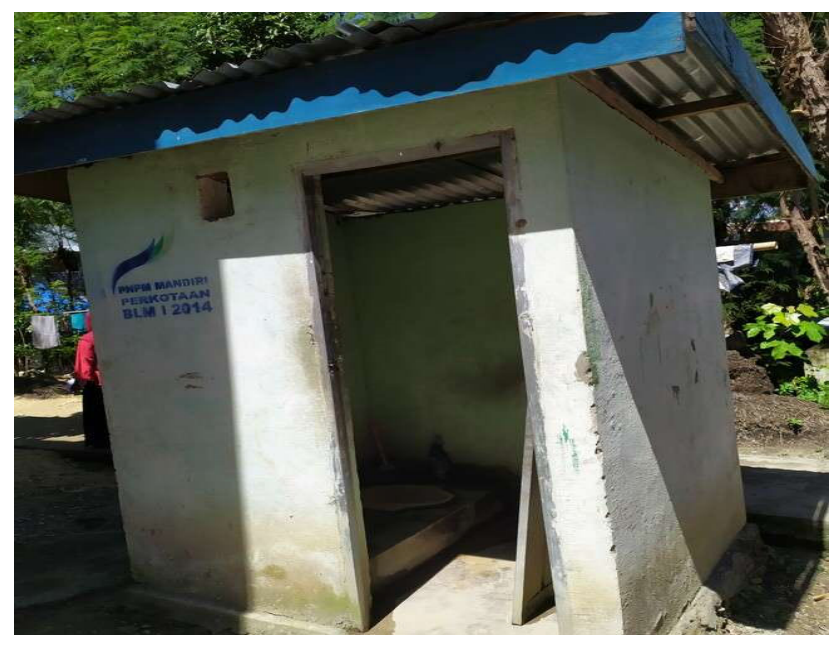

Gambar 1. Kamar mandi umum yang tidak berfungsi

Masih pada isu pembangunan infrastruktur, hampir semua rumah di Desa Pamboborang adalah rumah kayu. Dikarenakan, bahan untuk membuat rumah mudah didapatkan (dari alam). Namun, seiring berjalannya waktu penduduk yang perekonomiannya membaik memilih untuk membangun rumah dengan bata. Di lain pihak, penduduk yang perekonomiannya rendah membangun rumah dengan bahan kayu. Secara tidak langsung hal ini menggambarkan bahwa masyarakat setempat dengan perekonomian rendah jauh lebih banyak dibandingkan dengan yang mampu.

Beralih ke isu pembangunan non-infrastruktur ditunjukkan dengan rendahnya tingkat pendidikan masyarakat desa yang berdampak pada rendahnya upah pekerja yakni, pendapatan di bawah Upah Minimum Regional (UMR). Akibatnya belum terpenuhi kebutuhan dasar masyarakat, sehingga standar hidupnya rendah. Hal ini ditunjukkan dengan penetapan Desa Pamboborang sebagai Kampung KB oleh Pemerintah Daerah. Penetapan sebagai Kampung KB disebabkan ditemukannya kasus stunting 


\section{Jurnal ABDIMAS INDEPENDEN}

Vol. 2, No. 2, November 2021

(kerdil) pada anak-anak di Desa Pamboborang. Adapun salah satu penyebabnya yaitu, kurang gizi. Selain itu, ketidakmampuan rumah tangga dalam menyediakan nutrisi yang cukup untuk ibu dan anak mengakibatkan stunting. Hal ini berdampak pada kematian ibu dan anak yang cukup tinggi. Oleh karena itu, hampir semua perempuan di Desa Pamboborang sebagian besar memilih untuk melakukan KB. Jika memiliki anak dalam jumlah banyak dan jarak usia yang dekat, akan sangat membebani perempuan di Desa Pamboborang. Berdasarkan kondisi tersebut, disarankan agar menyediakan pemeriksaan secara berkala untuk ibu dan anak. Sekaligus memberikan pelatihan tentang penyediaan makanan bergizi sesuai kondisi lokal/kearifan lokal.

Di sisi lain, meskipun hampir semua perempuan di Desa Pamboborang melakukan KB, tetapi masih terdapat kasus pernikahan dini yang menjadi hal wajar di desa. Hal ini disebabkan oleh sistem nilai yang dijadikan cara "memaksa" anak menikah dan sistem nilai baru yang mengancam "penodaan" anak. Selain itu, dipicu karena masyarakat setempat banyak yang putus sekolah. Oleh karena itu, perlu tersedianya akses sekolah bagi warga desa (sekolah wisata, sekolah agama, dan lain sebagainya).

Sementara itu, isu pembangunan dalam bidang pertanian adalah rusaknya tanaman bawang dan belum ditemukan solusinya. Kerusakan tersebut disebabkan adanya penyakit yang menyerang tanaman bawang, sehingga berdampak pada rendahnya kualitas hasil panen, gagal bersaing, dan rendahnya harga jual. Konsekuensinya, berdampak pada ekonomi warga yakni, penghasilan petani bawang menurun.

Selain dari hasil pertanian yang dijual secara langsung, penghasilan warga desa juga diperoleh dari hasil produksi pertanian yang diolah menjadi bawang goreng. Namun, kurangnya pengetahuan yang dimiliki oleh warga tentang teknik pengolahan, pengemasan dan kualitas bawang goreng yang tahan lama masih menjadi kendala. Dampaknya pengusaha kesulitan 
mengatasi persaingan usaha dan menyebabkan turunnya penghasilan usaha. Perlu tersedianya pelatihan bagi mereka seperti pengolahan produk usaha rumah tangga (bawang goreng). Hal ini pun perlu ditindaklanjuti karena belum adanya wadah pemasaran jajan dan oleh-oleh/ pusat oleholeh di daerah tersebut. Sehingga, disarankan agar tersedianya pusat jajan dan oleh-oleh supaya produksi lebih lancar, yang kemudian bisa dikelola oleh masyarakat dan dikoordinir oleh Badan Usaha Milik Desa (BUMDES).

Usaha produksi lainnya di Desa Pamboborang adalah usaha pandai besi yang memproduksi samurai, parang, pisau dapur, keris, sabit, celurit dan lain sebagainya. Namun, tidak ada sumber daya alam di daerah sekitar yang digunakan sebagai bahan baku, sehingga bahan baku diperoleh dari luar daerah, seperti Kalimantan dan Makassar. Hal inilah yang mengakibatkan biaya produksi besi cukup besar. Selain itu, alat yang digunakan proses produksi kurang lengkap dan dilakukan secara manual.

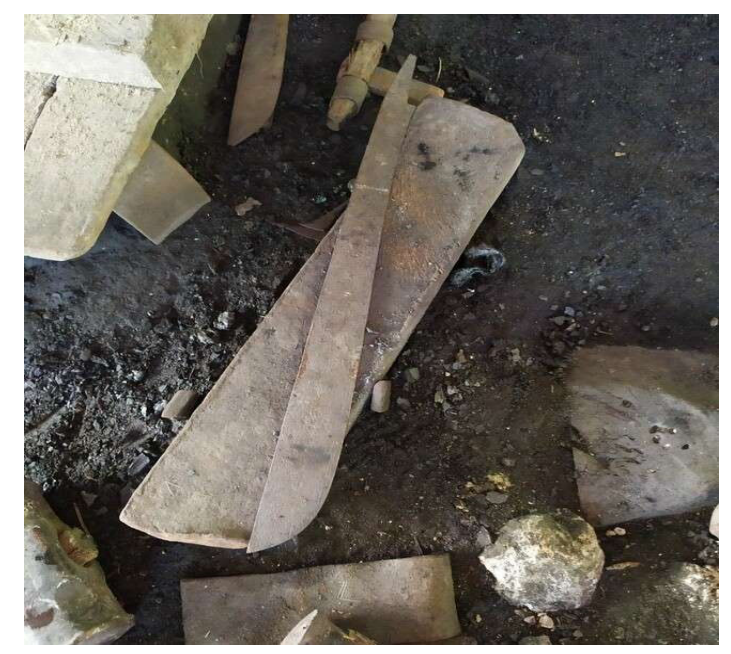

Gambar 2. Produksi besi

Usaha pengrajin besi dikelola oleh 6 (enam) kelompok, di mana ada ketua kelompok pengrajin besi dan anggotanya, rata-rata berjumlah 8 sampai 9 orang. Usaha ini dikelola oleh banyak pihak, karena itu perlu adanya transparansi dalam hal pengelolaan keuangan. Selain itu, untuk meningkatkan penjualan perlu adanya pelatihan untuk branding-merk dan perluasan jangkauan distribusi. 


\section{Jurnal ABDIMAS INDEPENDEN}

Vol. 2, No. 2, November 2021

Hal menarik pada usaha pengrajin besi ini adalah keterlibatan istriistri pengrajin besi dalam produksi kerajinan besi yang dikenal dengan sebutan Sibalipari. Tujuannya untuk memberikan aktivitas bermakna bagi istri-istri perajin besi dan meningkatkan pendapatan keluarga, sehingga meringankan beban kerja kepala keluarga.

Secara historis, pengetahuan dan keterampilan sebagai pengrajin besi pada masyarakat Desa Pamboborang berasal dari proses interaksi para pendahulu atau leluhur Desa Pamboborang dengan orang luar, melalui proses ekspansi kekuasaan. Oleh karena itu, ilmu yang diperoleh berdasarkan turun temurun dan tidak ada pengembangan keterampilan untuk menghasilkan inovasi. Dampaknya produk kerajinan besi yang dihasilkan kurang bervariasi, karena terbatasnya keterampilan dalam memproduksi hal-hal yang tidak biasa dibuat. Oleh karena itu, pengrajin besi perlu memunculkan produk lain hasil dari inovasi dan kreativitas pengrajin besi dalam bentuk cindera mata. Hal ini juga pernah dilakukan di Birra, dengan mendatangkan seorang pengrajin terampil dari Jawa yang memberi pelatihan pembuatan cindera mata, sehingga memicu kreativitas.

Terkait isu pembangunan sosial budaya, ditemukan adanya kesenjangan antara Dusun Galung Para dan Dusun Galung Para Selatan terkait pemilihan Kepala Desa (Pilkades) Pamboborang. Hal ini disebabkan terjadinya konflik horizontal antar wilayah atau warga dan adanya ketimpangan pembangunan wilayah. Implikasi tersebut berdampak pada komunikasi, solidaritas, silaturrahim antar warga terganggu, sehingga pembangunan terhambat. Akibatnya dalam musyawarah sulit menemukan mufakat dalam berdemokrasi. Selain itu, kurangnya saling percaya antara warga terhadap pemerintah desa (delegitimasi).

Sementara itu, budaya gotong royong warga desa mulai terkikis (misal pembajakan lahan pertanian). Kini warga memilih menggunakan alat pembajakan agar lebih praktis. Hal ini berdampak pada praktek gotong 
royong menjadi jarang untuk dilakukan. Lebih lanjut, warga desa semakin kehilangan kepekaan untuk saling membantu sama lain.

Di sisi lain, masyarakat di Desa Pamboborang masih melakukan ritual barzanji yang ditandai dengan pemotongan kambing untuk mengirimkan doa kepada orang yang telah meninggal. Kepercayaan masyarakat setempat apabila dilihat dari sisi agama tidak mencerminkan agama samawi. Hal ini mencerminkan rendahnya pengetahuan agama masyarakat setempat. Namun di sisi lain barzanji ini menjadi salah satu momen yang dapat memperkuat ikatan sosial masyarakat.

Keterikatan masyarakat di Desa Pamboborang masih sangat kuat. Dibuktikan dengan kebiasaan masyarakat apabila hendak merantau, mereka harus terlebih dahulu mengunjungi sumur suci (yang sudah dianggap keramat), yaitu sumur sandang. Hal-hal yang dilakukan seperti mandi di sumur dan membawa air sumur sandang pergi keluar daerah. Hal ini dipercaya oleh masyarakat setempat sebagai bentuk keselamatan masyarakat yang ingin merantau ke luar daerah.

Melihat sisi positif kekentalan budaya di Desa Pamboborang, sangat berpotensi sebagai pemersatu desa ini, seperti pada acara pernikahan, kematian, perayaan (seperti sunatan) yang bisa meredam konflik. Namun sangat disayangkan apabila kegiatan tersebut hanya sekadar ritual. Oleh karena itu, perlu adanya intervensi pemerintah desa atau regulasi desa sehingga ritual tidak hanya jadi "ritual formal", akan tetapi menjadi ruang publik untuk berdiskusi.

\section{Menyusun Simulasi Logical Framework}

Berdasarkan pengidentifikasian isu pembangunan dan penggalian potensi desa di atas, terdapat lima isu pembangunan di Desa Pemboborang, yaitu: keterbatasan pasokan air, rendahnya tingkat pendidikan, tingginya pernikahan usia muda, rendahnya penghasilan, dan meningkatnya konflik horizontal. Isu-isu pembangunan di atas, kemudian dimasukkan ke dalam 


\section{Jurnal ABDIMAS INDEPENDEN}

Vol. 2, No. 2, November 2021

desain program logical framework (lihat Gambar 3). Logical framework merupakan teknik merancang pembangunan secara partisipasif di mana pemecahannya dilakukan melalui diskusi dengan semua pemangku kepentingan, sehingga terbentuk kesepakatan tentang isu pembangunan yang akan diselesaikan dan bagaimana menformulasikan tujuan umum, tujuan spesifik, dan tujuan awal dari serangkaian aktivitas program (Arijanto 2017:8). Pembuatan desain program logframe memiliki tahap-tahap, yaitu: pertama memilih isu pembangunan yang dapat di atasi. Langkah ini merupakan memprioritaskan isu pembangunan yang mempengaruhi kesejahteraan desa di mana apabila diselesaikan akan menyelesaikan isu pembangunan lainnya.

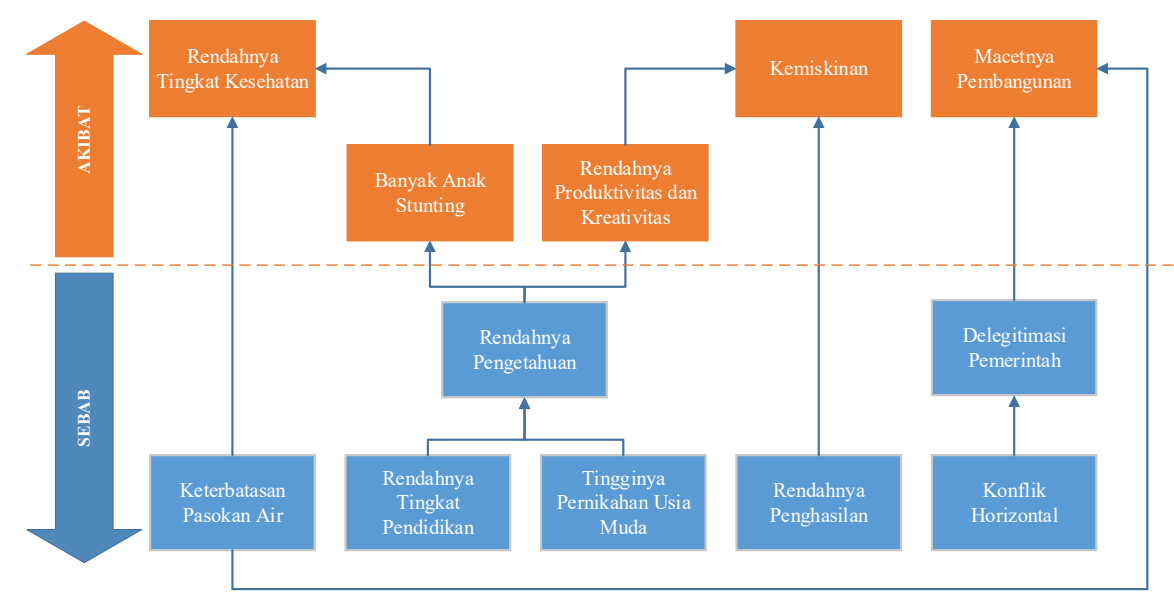

Gambar 3. Isu Pembangunan dalam Logframe

Langkah kedua, menyepakati isu pembangunan yang ingin diselesaikan dengan semua pemangku kepentingan. Pilihan isu pembangunan yang akan dijadikan sebagai program untuk meningkatkan kesejahteraan desa sangat tergantung pada peserta diskusi penyusunan program. Misalkan hasil diskusi menghasilkan pilihan isu pembangunan Desa Pamboborang adalah rendahnya penghasilan. Isu pembangunan tersebut dipilih mengingat luasnya dampak rentetan dari program peningkatan pendapatan warga desa di mana mata pencaharian warga desa, terdiri dari petani bawang, pandai besi dan pengusaha kecil. 
Langkah ketiga, menentukan tujuan umum atau tujuan akhir (goal) program sebagai wujud perubahan tentang status kesejahteraan manusia yang ingin dicapai (Arijanto 2021:73). Misalkan berdasarkan diskusi ditentukan tujuan umum untuk Desa Pemboborang adalah meningkatkan pendapatan warga desa. Selanjutnya tujuan khusus atau tujuan antara program (purpose) merupakan hasil yang ingin dicapai sebagai jembatan mencapai tujuan akhir (Arijanto 2021:73). Ditentukan tujuan khusus Desa Pemboborang adalah meningkatkan hasil panen bawang, pesanan perkakas besi, dan penjualan oleh-oleh. Langkah keempat, menentukan aksi perubahan. Aksi perubahan untuk meningkatkan pendapatan petani bawang, antara lain: memfasilitasi ketersediaan input pertanian bawang kepada pengemban tugas di bidang pertanian dan sektor lain yang terkait dan mendirikan koperasi petani bawang di desa di mana menjadi lembaga yang mengatur kebijakan harga jual bawang. Aksi perubahan untuk meningkatkan pendapatan pandai besi dengan mengaktifkan BUMDES, sehingga melalui BUMDES dapat diberikan pelatihan dan pemberian modal. Aksi perubahan berikutnya adalah membuat desa wisata yang nantinya akan memberikan dampak positif terhadap segala sektor, baik ekonomi maupun budaya desa tersebut. Melihat dari potensi desa yang dapat diwujudkan sebagai objek wisata, diantaranya adalah sebagai berikut: pandai besi dan ritualnya, makam pendiri, sumber Air atau sumur sandang, bukit Soe, bukit Pamboborang, agrowisata, wisata bintang, dan wisata sunrise atau sunset. Namun, dalam membangun desa wisata membutuhkan akses jalan yang layak untuk dilewati berbagai moda transportasi. Selain itu, perlu adanya fasilitas umum seperti, toilet umum, parkir, dan tempat ibadah, tentu hal ini juga berkaitan dengan tersedianya air bersih yang cukup untuk digunakan banyak orang.

Aksi perubahan untuk meningkatkan penghasilan masyarakat secara umum dengan mendirikan usaha rumah makan atau warung sebagai destinasi wisata kuliner. Lainnya yang perlu diperhatikan yaitu pengelolaan 


\section{Jurnal ABDIMAS INDEPENDEN}

Vol. 2, No. 2, November 2021

sampah. Ketika terjadi peningkatan pengunjung atau wisatawan sangat dimungkinkan terjadi penumpukan sampah. Hal ini termasuk pula dalam manajemen wisata. Hal tersebut bisa didukung dengan adanya Sekolah Pariwisata Berbasis Budaya (yang menyediakan ilmu manajemen pariwisata dengan tetap memperhatikan situs budaya sekaligus sumber daya bagi pengelolaan desa wisata). Suplemen lainnya agar memperkuat produk hasil masyarakat setempat perlu didirikan pusat jajan dan oleh-oleh agar produksi dan pemasaran lebih lancar. Perwujudan solusi ini dapat berupa, Desa Wisata Pendidikan dan Sentra usaha pandai besi, yang tentu memerlukan kerja sama dengan BUMDES.

\section{Gagasan Konsep Kesejahteraan}

Pemberdayaan merupakan sebuah jalan menuju masyarakat makmur dan sejahtera. Proses pemberdayaan dianalogikan seperti menyalakan lentera. Lentera memiliki bahan bakar minyak yang sudah ada di dalamnya. Sekitar kita menjadi terang benderang dengan memantikkan api dan terbakarlah sumbu lentera. Dalam konteks proses pemberdayaan, lentera itu adalah manusia, organisasi masyarakat, dan institusi publik. Sementara, para agen perubahan hanya bertugas memantik percikan api ke sumbu lentera yang sudah dibasahi minyak. Sepanjang minyak itu ada, lentera akan terus menyala. Demikian juga sepanjang semangat di dada manusia menyala, maka upaya untuk memperbaiki diri akan selalu tumbuh (Arijanto 2021:31).

Konsep kesejahteraan desa ini didasarkan pada studi kasus di Desa Pamboborang dan simulasi isu pembangunan dalam logframe Desa Pamboborang. Gagasan ini berangkat dari impian tentang kondisi ideal yang diimpikan akan terjadi di masa depan di Desa Pamboborang yaitu menjadi sebuah desa dengan tanah pertanian yang luas dan subur, serta dikelilingi oleh industri dan daerah wisata. Desa Pamboborang memiliki warga desa di mana kelompok usia produktifnya berpengetahuan, berketerampilan, 
bermoral, dan berakhlak. Mereka ini memiliki semangat dalam meningkatkan kualitas diri, sehingga hasil dari aktivitasnya baik sebagai petani, pengrajin besi, dan pengusaha kecil mampu bersaing di pasaran. Sementara itu, pihak pemerintah desa memiliki sifat mengayomi, bertanggung jawab, dan berpihak pada masyarakat kecil. Apabila impian kondisi ideal desa dituangkan dalam visi desa, maka menjadi: "sebuah desa di mana warga dan pemimpinnya menghargai martabat manusia, saling peduli, dan bekerja sama untuk meningkatkan kesejahteraan dan kemakmuran bersama" (Arijanto 2021:94).

Tindaklanjut dari impian desa ideal dilakukan melalui pemberdayaan Desa Pamboborang dengan mengoptimalkan segala potensi yang dimiliki untuk mencapai tujuan akhir, yaitu meningkatkan pendapatan warga desa. Dalam rangka meraih tujuan akhir tersebut, dirancang pemberdayaan berkualitas di mana masyarakat turut dilibatkan dalam menyusun programprogram aksi secara partisipasif untuk meniadakan isu pembangunan desa (lihat Gambar 4).

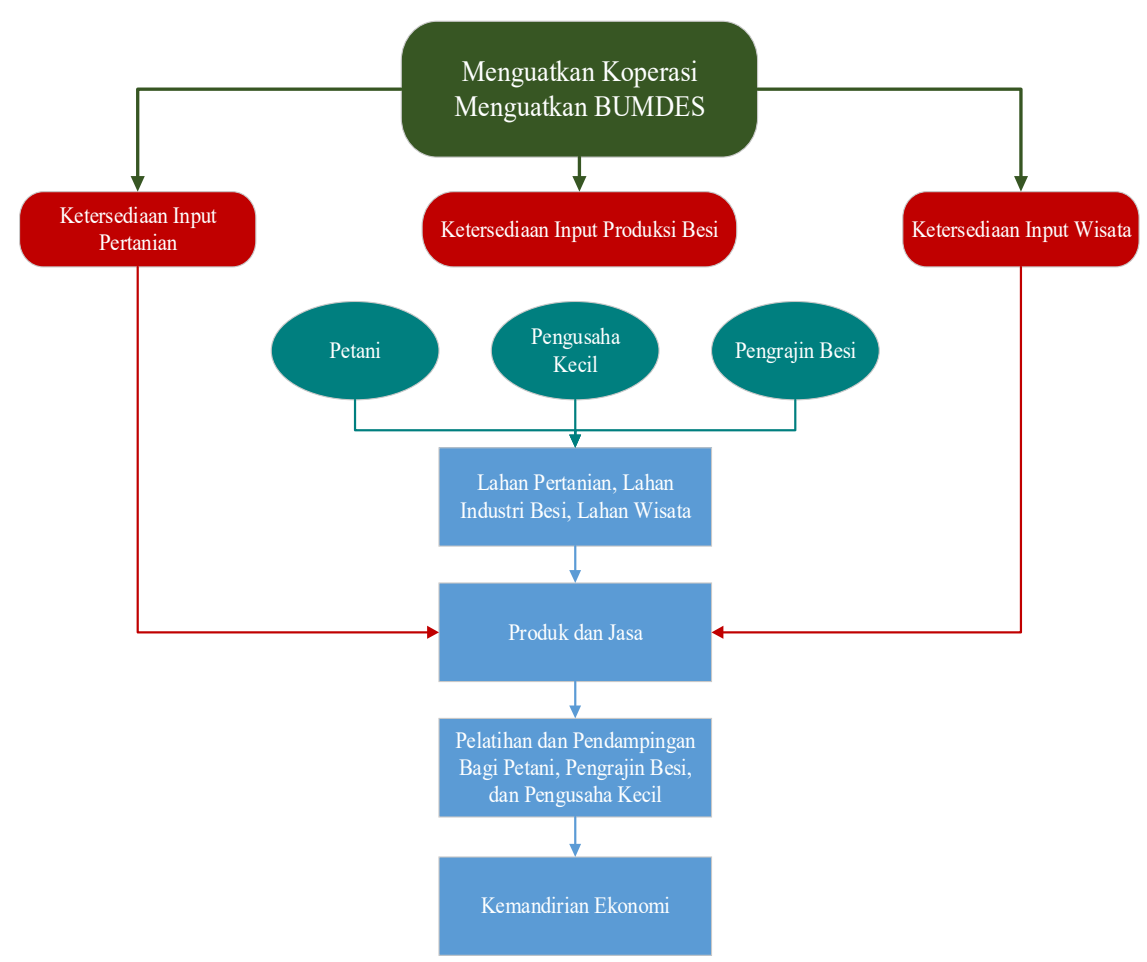




\section{Jurnal ABDIMAS INDEPENDEN}

Vol. 2, No. 2, November 2021

Tujuan akhir desa Pamboborang meningkatkan pendapatan warga merupakan harapan untuk mencapai kemandirian ekonomi. Berangkat dari penguatan lembaga desa yaitu, koperasi dan BUMDES. Dampaknya menjaga ketersediaan input pertanian, input poduksi besi, dan input wisata yang selanjutnya menghasilkan produk dan jasa. Produk dan jasa merupakan konsekuensi dari ketersediaan lahan pertanian, lahan industri, dan lahan wisata di mana didukung dengan pemberian kesempatan mendapatkan pelatihan dan pendampingan yang difasilitasi oleh pemerintah desa sehingga mencapai kemandirian ekonomi.

\section{KESIMPULAN DAN SARAN}

Berbagai isu pembangunan yang ditemukan di Desa Pamboborang menegaskan sebagai tempat bagi pihak marginal. Oleh karena itu, dibutuhkan program aksi perubahan, sehingga mampu membebaskan Desa Pamboborang dari isu pembangunan yang ada. Melalui desain program logframe, agen perubahan dalam hal ini adalah para peneliti bersama dengan pemangku kepentingan menentukan isu pembangunan desa yang memiliki dampak luas bagi isu pembangunan lainnya. Hasil dari kegiatan pengabdian ini memimpikan Desa Pamboborang sebagai desa yang sejahtera melalui kemandirian ekonomi. Dengan meningkatkan produktivitas produksi bawang, kerajinan besi, dan pengusaha kecil dan beberapa program aksi pemberdayaan desa.

\section{DAFTAR PUSTAKA}

Arijanto. 2017. Nandur Ngunduh. Jakarta Selatan: Yayasan Rumah Peneleh. Arijanto. 2021. Memanusiakan Manusia: Sebuah Pendekatan Kemandirian Menuju Kemakmuran Dan Kesejahteraan. edited by J. N. Kusteja. Malang: Penerbit Peneleh.

Mulawarman, AD, Ari Kamayanti, Adel Hikam Arif, Arif Faizar Wijaya, Ahmad 
Fauzi, Amalia Sandy Pertiwi, and Amelia Indah Kusdewanti. 2020. Catatan Relawan Riset Peneleh: Menggali Potensi Desa Di Jabung, Malang. edited by A. D. Mulawarman, A. Kamayanti, N. Q. Lutfillah, and D. Djuharni. Malang: Penerbit Peneleh. 